\section{Organic Management of Cucumber Beetles in Watermelon and Muskmelon Production}

\author{
Gary R. Cline, John D. Sedlacek ${ }^{1}$, Steve L. Hillman, \\ Sharon K. Parker, and Anthony F. Silvernail
}

AdDitional Index words. Acalymma vittatum, Diabrotica undecimpunctata, reflective mulch, companion plants, pyrethrin, Cucumis melo, Citrullus lanatus, Fagopyrum esculentum, Raphanus sativus

Summary. Organic methods for managing striped cucumber beetles (Acalymma vittatum) and spotted (Diabrotica undecimpunctata) cucumber beetles were examined in the production of watermelon (Citrullus lanatus) and muskmelon (Cucumis melo) using sticky traps to monitor beetle populations. In 2002, the numbers of trapped striped and total (striped + spotted) cucumber beetles were significantly $(P \leq 0.05)$ reduced by the combined use of three companion plants thought to repel cucumber beetles [radish (Raphanus sativus), tansy (Tanacetum vulgare), and nasturtium (Tropaeolum spp.)] or by the combined use of three companion plants known to attract beneficial insects [buckwheat (Fagopyrum esculentum), cowpeas (Vigna unguiculata), and sweetclover (Melilotus officinalis)]. In 2003 and 2004, the single companion plant treatment consisted of the combined use of radish and buckwheat. In 2003, use of aluminum-coated plastic mulch (Al-plastic) or companion plants significantly increased muskmelon yields and vine cover, while significantly reducing numbers of trapped striped, spotted, and total cucumber beetles. The use of pyrethrin insecticide did not significantly affect muskmelon yields or vine cover. In 2004, the beneficial effects of companion plant and $\mathrm{Al}$-plastic treatments on muskmelon yields and vine cover were also significant and similar to those in 2003; however, these treatments only affected early season numbers of trapped beetles. The use of rowcovers significantly increased muskmelon yields and vine cover in 2003 and 2004 and did not affect beetle populations after rowcover removal. It was concluded that use of companion plants and Al-plastic increased muskmelon yields and vine cover while reducing populations of cucumber beetles, particularly striped cucumber beetles. The use of rowcovers also increased muskmelon yields and vine cover.

$\mathrm{S}$ triped and spotted cucumber beetles are important insect pests of cucurbits and vectors of the causal agent of bacterial wilt (Erwinia tracheiphila), the most serious disease threat of muskmelon in Kentucky (Hoffman, 1998; Rowell et al., 2002). Adult cucumber beetles and larvae also can cause damage by feeding on cucurbit roots, shoots, and flowers.

Synthetic insecticides such as imidacloprid, permethrin, and carbaryl can be used to control cucumber beetles in conventional vegetable production but are precluded from use in organic production (Rowell et al., 2002). Production of organically grown vegetables is increasing, and new effective organic management practices for cucumber beetles are needed due to the limitations of

Atwood Research Facility, Kentucky State University, Frankfort, KY 40601

${ }^{1}$ Corresponding author. E-mail: john.sedlacek@ kysu.edu. current practices, which include the use of rowcovers and the botanical insecticide, rotenone (Jolly, 1998; Lopez, 1998; Smith and Henderson, 1998). Rowcovers are only useful until flowering, when they must be removed to allow insect pollination. Rotenone is highly toxic to cucumber beetles, but residual effects only persist for 1 to $3 \mathrm{~d}$ because it is not stable in sunlight (Ware, 1994). Also, rotenone is as toxic to humans as many synthetic insecticides, and many organic growers are reluctant to use it (Rowell et al., 2002; Ware, 1994). Pyrethrin is an organic insecticide that is less toxic to humans than rotenone (Rowell et al., 2002) and may be an effective insecticide for cucumber beetles. It is a contact insecticide that causes insects to leave protected areas, exposing them to the insecticidal spray.

Several other organic methods may reduce populations of cucumber beetles. Caldwell and Clarke (1998, 1999) reported that cucumber beetle densities on squash (Cucurbita pepo) were five times less with aluminumcoated plastic (Al-plastic) mulch than with black plastic mulch. No insecticidal treatment was required with Al-plastic, making it cost-effective. Numbers of cucumber beetles in watermelon have been reduced using $\mathrm{Al}$-plastic in place of black plastic mulch, but the results were not statistically significant $(P>0.05$; Andino and Motsenbocker, 2004). Companion plants may be planted near cucurbits to attract insects that prey on cucumber beetles. These beneficial insects include pennsylvania leatherwings (Chauliognathus pennsylvanicus) and tachinid flies such as Celatoriae diabrocitae and Celatoriae setosa (Platt et al., 1999). Companion plants thought to attract beneficial insects include buckwheat, cowpeas, and sweetclover (Bowman et al., 1998; Platt et al., 1999). Other types of companion plants are thought to repel cucumber beetles, including radish, nasturtium, and tansy (Rodale Press, 1978). Cucumber beetle numbers in cucumber (Cucumis sativus) have been reduced using corn (Zea mays) and broccoli (Brassica oleracea var. italica) companion plants (Bach, 1980a, 1980b); however, beetle numbers in squash were increased when plots were edged with tomato

\begin{tabular}{lllc}
\hline $\begin{array}{l}\text { Units } \\
\begin{array}{l}\text { To convert U.S. to SI, } \\
\text { multiply by }\end{array}\end{array}$ & U.S unit & SI unit & $\begin{array}{l}\text { To convert SI to U.S., } \\
\text { multiply by }\end{array}$ \\
\hline 0.4047 & $\mathrm{acre}(\mathrm{s})$ & $\mathrm{ha}$ & 2.4711 \\
0.3048 & $\mathrm{ft}$ & $\mathrm{m}$ & 3.2808 \\
0.0929 & $\mathrm{ft}^{2}$ & $\mathrm{~m}$ & 10.7639 \\
2.54 & inch $(\mathrm{es})$ & $\mathrm{cm}$ & 0.3937 \\
0.4536 & $\mathrm{lb}$ & $\mathrm{kg}$ & 2.2046 \\
1.1209 & $\mathrm{lb} / \mathrm{acre}$ & $\mathrm{kg} \cdot \mathrm{ha}^{-1}$ & 0.8922 \\
1.6093 & mile $(\mathrm{s})$ & $\mathrm{km}$ & 0.6214 \\
70.0532 & $\mathrm{oz} / \mathrm{acre}$ & $\mathrm{g} \cdot \mathrm{ha}^{-1}$ & 0.0143 \\
7.4892 & $\mathrm{oz} / \mathrm{gal}$ & $\mathrm{g} \cdot \mathrm{L}^{-1}$ & 0.1335 \\
2.2417 & ton $/ \mathrm{acre}$ & $\mathrm{Mg} \cdot \mathrm{ha}^{-1}$ & 0.4461
\end{tabular}


(Solanum lycopersicum) plants (Bach, 1988). Thus, beetles may be affected differently in various polyculture plantings.

The objective of this research was to examine the use of companion plants, Al-plastic, and pyrethrin as organic methods for managing $\mathrm{Cu}^{-}$ cumber beetles in the production of watermelon and muskmelon.

\section{Materials and methods Experimental approach}

In 2002, a field experiment was conducted at the Kentucky State University Research Farm near Frankfort, $\mathrm{KY}$, to examine the potential of companion plants and plastic mulch for cucumber beetle management. Watermelon was used in the initial experiment because it attracts cucumber beetles but is not susceptible to bacterial wilt disease. Thus, early crop failure was minimized, allowing treatment effects on beetle populations to be monitored over the entire growing season. The 2002 treatments most effective in reducing numbers of cucumber beetles were used in 2003 and 2004 experiments with muskmelon, which is susceptible to bacterial wilt. Conventional fertilizer and pesticides were used in 2002 in the initial watermelon experiment, whereas 2003 and 2004 cropping methods were in accordance with Kentucky and national organic standards although the land was not certified as organic. Cooperative extension soil tests were used to assure that sufficient potassium $(\mathrm{K})$ and phosphorus (P) were supplied in accordance with state guidelines (Rowell et al., 2002). Melons were grown on black plastic mulch in all treatments, including controls, except when Al-plastic (Clarke Ag Products, Greenwood, VA) was used. In all years, trickle irrigation was used and plots were cropped with corn the preceding year. Melon yields were based on plot areas cropped with melons. The experiment was rotated between two sites in following years, and dates of experimental activities are presented in Table 1.

2002 EXPERIMENT. Four treatments were replicated three times in a randomized block design to examine cucumber beetle management in watermelon grown using plastic mulch. Treatments included: 1 ) a control, 2) the use of Al-plastic in place of

Table 1. Schedule of activities for watermelon and muskmelon experiments conducted from 2002-04 at the Kentucky State University Research Farm in Frankfort, KY.

\begin{tabular}{|c|c|c|c|}
\hline \multirow[b]{2}{*}{ Activity } & \multicolumn{3}{|c|}{ Year/crop } \\
\hline & $\begin{array}{c}2002 \\
\text { Watermelon }\end{array}$ & $\begin{array}{c}2003 \\
\text { Muskmelon }\end{array}$ & $\begin{array}{c}2004 \\
\text { Muskmelon }\end{array}$ \\
\hline Soil plowed & 25 Apr. & 12 Mar. & 20 Mar. \\
\hline Soil disked & 10 May & 26 Mar. & 4 Apr. \\
\hline First rototilling & 12 May & 29 May & 5 May \\
\hline Companion plants planted & 20-24 May & 29 May & 13 May \\
\hline Fertilizer added & 29 May & 29 May & 25 May \\
\hline Second rototilling & 29 May & 29 May & 25 May \\
\hline Plastic mulch laid & 31 May & 23 June & 27 May \\
\hline Melons planted & 31 May & 24 June & 10 June \\
\hline Rowcovers added & - & 24 June & 21 June \\
\hline Sticky traps installed & l June & 25 June & 17 June \\
\hline Weeds cultivated & 17 June, 2 July & 9, 25 July & 8,16 July \\
\hline Rowcovers removed & - & 18 July & 15 July \\
\hline Harvests & $12,21,29$ Aug. & $\begin{array}{c}21,25,29 \text { Aug. } \\
2,5,9 \text { Sept. }\end{array}$ & $\begin{array}{l}\text { 10, 13, 17, 23, } \\
27 \text { Aug. }\end{array}$ \\
\hline
\end{tabular}

black plastic mulch, 3) companion plants thought to repel cucumber beetles (radish, nasturtium, and tansy), and 4) companion plants thought to attract beneficial insects (buckwheat, cowpea, and sweetclover).

All plots were separated by at least $50 \mathrm{ft}$ of mowed tall fescue grass (Festuca arundinacea). Plots not containing companion plants were $42 \mathrm{ft}$ wide and contained four $50-\mathrm{ft}$ rows of watermelon. Between-row spacing was $10 \mathrm{ft}$, and the in-row melon spacing was $4 \mathrm{ft}$. In the two treatments including companion plants, plots were enlarged to contain an additional five rows of companion plants. In these treatments, companion plant rows alternated with watermelon rows such that watermelon rows had a row of companion plants on either side.

In one companion plant treatment, single rows of combined cucumber beetle-repelling plants were $3 \mathrm{ft}$ wide. Alternating nasturtium seeds and tansy divisions were manually planted down the center of these rows at 2 - $\mathrm{ft}$ intervals, and 'Summer Cross No. 3' daikon radish plants were seeded 2 inches apart along both outside borders of each companion plant row (Table 1).

In the other companion plant treatment, each row of beneficial insect-attracting plants was $9 \mathrm{ft}$ wide and contained randomized 3 -ft-wide subrows of buckwheat, cowpea, and annual white sweetclover. Buckwheat and cowpea were drilled at seeding rates of 132 and $119 \mathrm{lb} /$ acre, respectively, whereas sweetclover seed was broadcast at $74 \mathrm{lb} /$ acre and was manually incorporated. After flowering began, $50 \%$ of the buckwheat was manually cut at 3 -week intervals to remove flowers, promoting flowering over the entire growing season. Buckwheat was cut in the middle $25-\mathrm{ft}$ segment of each row or in the remaining two 12.5-ft end segments of each row.

The plots were plowed to a depth of 8 inches and were rototilled (Table 1). All plots received $143 \mathrm{lb} /$ acre of $\mathrm{K}$ as potash and $60 \mathrm{lb} /$ acre of $\mathrm{N}$ as ammonium nitrate $\left(\mathrm{NH}_{4} \mathrm{NO}_{3}\right)$, which were incorporated by rototilling. Three-week-old 'Stars and Stripes' watermelon seedlings were planted manually through 5 -ft-wide Al-plastic or black plastic mulch. Chlorothalonil fungicide at $2.2 \mathrm{lb} /$ acre (a.i.) was applied at 7 - to 10 -d intervals for disease control. Weeds were controlled by rototilling between the plastic mulch on 17 June and 2 July. Also, ethylfluralin herbicide was applied to all plots at a rate of $1.43 \mathrm{lb} /$ acre (a.i.) on 2 July, and was activated by overhead irrigation on 2 and 3 July. Rows of companion plants were weeded manually. Melons were side-dressed with $20 \mathrm{lb}$ /acre of $\mathrm{N}$ as dissolved $\mathrm{NH}_{4} \mathrm{NO}_{3}$ applied through the irrigation system on 15 July.

To monitor populations of $\mathrm{cu}-$ cumber beetles, two 6-inch-square double-sided yellow sticky traps were placed in the middle two melon rows 
of each plot. The tops of the traps were positioned $2 \mathrm{ft}$ above the soil surface and $14 \mathrm{ft}$ from the ends of the rows. Beetles on the traps were counted weekly and the traps were replaced.

Melons were harvested on 12 , 21 , and 29 Aug. from a $24 \times 20-\mathrm{ft}$ area in the middle two watermelon rows of each plot containing 12 watermelon plants. Marketable melons (U.S. Department of Agriculture, 1997a) were counted and weighed individually.

2003 EXPERIMENT. In 2003, muskmelon was grown organically on plastic mulch, and treatments were arranged in a $4 \times 2$ split-plot, factorial, randomized block design replicated three times. Four main plot treatments included a control treatment and use of Al-plastic mulch, companion plants (radish + buckwheat), or pyrethrin insecticide (Pyganic EC insecticide; Mclaughlin Gormerly King Co., Minneapolis). Split-plot treatments consisted of the presence or absence of rowcovers. The 2003 companion plant treatment included the combined use of radish as a beetlerepelling plant and buckwheat as a beneficial insect-attracting plant.

Except for the companion plant treatment, main plots were $40 \times 28 \mathrm{ft}$ and were divided into two $20 \times 28-\mathrm{ft}$ subplots. Main plots were separated by at least $60 \mathrm{ft}$. Soil preparation was similar to that in 2002 (Table 1 ), except that fertilizer approved for organic production (All Season Nature Safe; Advanced Turf Solutions, Louisville, $\mathrm{KY}$ ), was used to provide $\mathrm{N}$ ( $155 \mathrm{lb} /$ acre), $\mathrm{P}(3 \mathrm{llb} /$ acre $)$, and $\mathrm{K}(125 \mathrm{lb} / \mathrm{acre})$ to all plots. The fertilizer included feather, bone, and blood meals. In each subplot, a total of 48 'Eclipse' muskmelon seedlings were planted into 4 -ft-wide black plastic or Al-plastic in four 20$\mathrm{ft}$ rows (12 plants/row) spaced $7 \mathrm{ft}$ apart with an in-row spacing of 18 inches. Planting was delayed until 24 June due to wet soil.

Plot widths were increased from 28 to $40 \mathrm{ft}$ to include three companion plant rows. The companion plant rows were parallel to muskmelon rows and were placed between the middle two muskmelon rows and along each of the plot borders adjacent to the two outside watermelon rows. Each 4-ft-wide companion plant row contained a center 3 -ft-wide
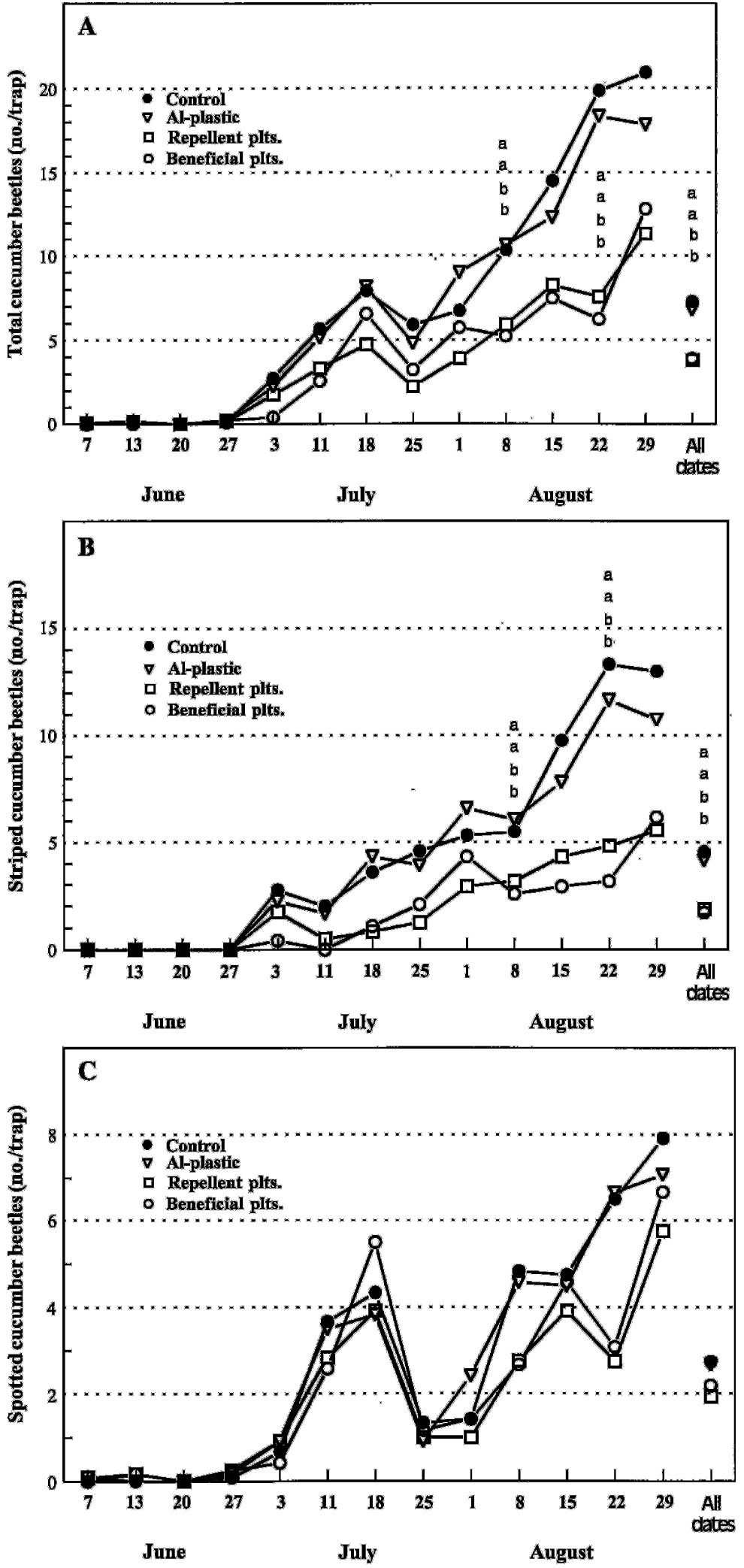

Fig. 1. Effects of aluminum-coated plastic mulch (Al-plastic), insect-repelling companion plants (Repellent plots), and beneficial insect-attracting companion plants (Beneficial plots) on numbers of trapped (A) total cucumber beetles, (B) striped cucumber beetles, and (C) spotted cucumber beetles in 2002 in watermelon grown at Frankfort, KY. On each date, values followed by different letters were significantly different $(P \leq 0.05)$. 
row of buckwheat bordered on each side by 0.5 -ft-wide rows of daikon radish. Seeding methods and rates were the same as in 2002.

Light-weight 8-ft-wide translucent polypropylene rowcovers (SuperLite Insect Barriers; Gardens Alive, Lawrenceburg, IN) were installed randomly in one subplot in each main plot soon after planting and were removed after 3 weeks to allow insect pollination. These rowcovers were designed to transmit $95 \%$ of sunlight, while allowing almost no heat buildup.

Rowcovers straddled the plastic mulch and confined vines to the mulch area. Vines from plants not receiving rowcovers were manually confined to the mulch area to facilitate mechanical weed control between plastic mulch strips.

Plots in the pyrethrin treatment were sprayed weekly from 5 July to 20 Aug. with pyrethrin insecticide at a target rate of $0.9 \mathrm{oz} /$ acre (a.i.). The insecticide was applied manually with a backpack sprayer at a concentration (a.i.) of $0.028 \mathrm{oz} / \mathrm{gal}$ of water.

Two sticky traps were centered in the middle two melon rows of each subplot (four traps/main plot) and were changed weekly to monitor populations of striped and spotted cucumber beetles. Before rowcover removal, all four traps in each main plot were located in the subplot not containing rowcovers. The percentage of vine cover of subplots was visually rated on 14 and 27 Aug. Marketable muskmelons (U.S. Department of Agriculture, 1997b) were harvested on six dates from 21 Aug. to 9 Sept. (Table 1) from a $168-\mathrm{ft}^{2}$ area in the middle two rows of each subplot containing 16 melon plants.

2004 EXPERIMENT. The 2003 experiment was repeated in 2004, except that the 2003 pyrethrin insecticide main plot treatment was replaced with a 2004 treatment that included a combination of Al-mulch and companion plants. Thus, main plot treatments included a control treatment and use of Al-plastic, companion plants (radish + buckwheat), or Al-plastic plus companion plants. Split plot treatments again consisted of the presence or absence of rowcovers. Muskmelon was planted on 10 June and was harvested on five dates from 10 to 27 Aug., as described in Table 1.
In each year, analysis of variance was used to test for significance ( $P \leq$ 0.05 ) of main and subplot treatments and interactive effects among these treatments. Significant differences among means of main plot treatments or subplot treatments were determined using the least significant difference.

\section{Results and discussion 2002 experiment}

COMPANION PLANTS. In the companion plant treatment designed to attract beneficial insects, buckwheat grew faster and produced flowers earlier and over a longer time period than sweet clover or cowpea. Buckwheat flowered 3 weeks after seeding, and cutting practices promoted flowering throughout the growing season. For companion plants included to repel cucumber beetles, radish survived well and produced abundant vegetation, which is thought to repel insects (Rodale Press, 1978). Tansy and especially nasturtium had lower survival rates and produced less vegetation than radish. Only minimal flowering of tansy or nasturtium was observed. Also, buckwheat and radish required less weed control than other companion plants.

WATERMELON YIELDS. No significant differences in watermelon yields were detected among treatments in 2002 , indicating that use of Al-plastic or companion plant treatments did not adversely affect watermelon production. The total mean yield was 42 tons/acre or 3300 melons/acre.

Cucumber beetles. Few cucumber beetles were caught on sticky traps in June (Fig. 1, A-C). In July and August, more total (spotted plus striped) cucumber beetles were trapped in control and Al-plastic treatments than in the repellent plant or beneficial insect treatments (Fig. 1A). These differences were significant for all dates combined and on 8 and 22 Aug., when about half as many total beetles were trapped in the two companion plant treatments as in the control treatment. The numbers of total trapped beetles did not vary significantly between repellent plant and beneficial insect treatments, suggesting that the physical barrier to beetle movement provided by the rows of companion plants may be more important than any attractant or repellent properties of the plants. Bach (1980a, 1980b) reported that cucumber beetle numbers/plant were significantly decreased by diversity when cucumber was interplanted with rows of corn and broccoli. The fact that the Al-plastic did not reduce the trap counts of striped beetles may have been due to the late arrival of the beetles in July, when most of the Al-plastic was covered with vines, reducing its ability to reflect light (Fig. 1).

In squash and muskmelon, cucumber beetle populations of one beetle per plant have been considered acceptable, and this value corresponds to 15 cucumber beetles per sticky trap in squash (Brust and Foster, 1999; Caldwell and Clarke, 1999). The numbers of trapped total beetles in control and Al-plastic treatments exceeded 15 beetles per trap, whereas trapped beetle numbers in the two

Table 2. Effects of treatments on yields and vine cover of muskmelon grown in 2003 at Frankfort, KY.

\begin{tabular}{|c|c|c|c|c|}
\hline \multirow[b]{2}{*}{ Treatments } & \multicolumn{2}{|c|}{ Muskmelon yields } & \multicolumn{2}{|c|}{$\begin{array}{c}\text { Muskmelon vine } \\
\text { cover (\%) }\end{array}$} \\
\hline & $(\text { tons/acre })^{\mathrm{z}}$ & $(1000 \text { melons/acre })^{\mathrm{y}}$ & 14 Aug. & 27 Aug. \\
\hline \multicolumn{5}{|c|}{ Main plot treatments } \\
\hline Control & $16.2 \mathrm{~b}^{\mathrm{x}}$ & $6.16 \mathrm{c}$ & $73 \mathrm{~b}$ & $59 \mathrm{~b}$ \\
\hline Al-plastic ${ }^{v}$ & $28.4 \mathrm{a}$ & $10.30 \mathrm{a}$ & $96 \mathrm{a}$ & $86 \mathrm{a}$ \\
\hline Comp. plant ${ }^{\mathrm{u}}$ & $23.1 \mathrm{ab}$ & $8.55 \mathrm{ab}$ & $83 \mathrm{ab}$ & $74 \mathrm{ab}$ \\
\hline Pyrethrin & $20.0 \mathrm{~b}$ & $7.07 \mathrm{bc}$ & $74 \mathrm{~b}$ & $63 \mathrm{~b}$ \\
\hline \multicolumn{5}{|c|}{ Subplot treatments } \\
\hline No rowcovers & $17.7 \mathrm{~b}$ & $6.41 \mathrm{~b}$ & $73 \mathrm{~b}$ & $60 \mathrm{~b}$ \\
\hline Rowcovers & $26.1 \mathrm{a}$ & $9.62 \mathrm{a}$ & 85 a & $80 \mathrm{a}$ \\
\hline
\end{tabular}


companion plant treatments did not exceed this value (Fig. 1A).

The effects of companion plants on striped cucumber beetles were similar to those described for total beetles and were also significant on two dates and for all dates combined (Fig. 1B). The numbers of trapped spotted cucumber beetles were lower than those of striped beetles and were unaffected by treatments (Fig. 1C). Thus, treatment affected striped more than spotted beetles, in agreement with Platt et al. (1999).

\section{3 experiment}

Because both types of companion plant treatments significantly reduced numbers of trapped cucumber beetles in 2002, a companion plant to attract beneficial insects (i.e., buckwheat) and a companion plant to repel cucumber beetles (i.e., radish) were combined into a single main plot treatment in 2003. Buckwheat and radish were selected for reasons relating to growth, flowering, and weed control as described previously. Although Al-plastic was not effective as a beetle deterrent in 2002 , it was included as a main plot treatment in 2003 because it has been effective in other cucumber beetle studies (Caldwell and Clarke, 1998, 1999). Also, the effects of Al-plastic in 2002 may have been related to the late arrival of the cucumber beetles, as noted previously. Additional main plot treatments included use of pyrethrin and a control, whereas the use of rowcovers was examined in subplot treatments.

Interactions between main plot treatments and rowcover treatments on dependent variables were not significant in the analysis of variance. Thus, main plot treatments were analyzed for combined rowcover treatments and vice versa. There were no main or subplot treatment effects on the weights of individual muskmelons, which averaged $5.4 \mathrm{lb}$ for combined treatments

\section{Main plot treatment effects}

MusKmelon YIELDS. The use of Al-plastic and companion plants increased muskmelon yields. The total weight and numbers of muskmelon were highest in the Al-plastic treatment and were significantly greater $(75 \%$ and $66 \%$, respectively) than those in the control treatment
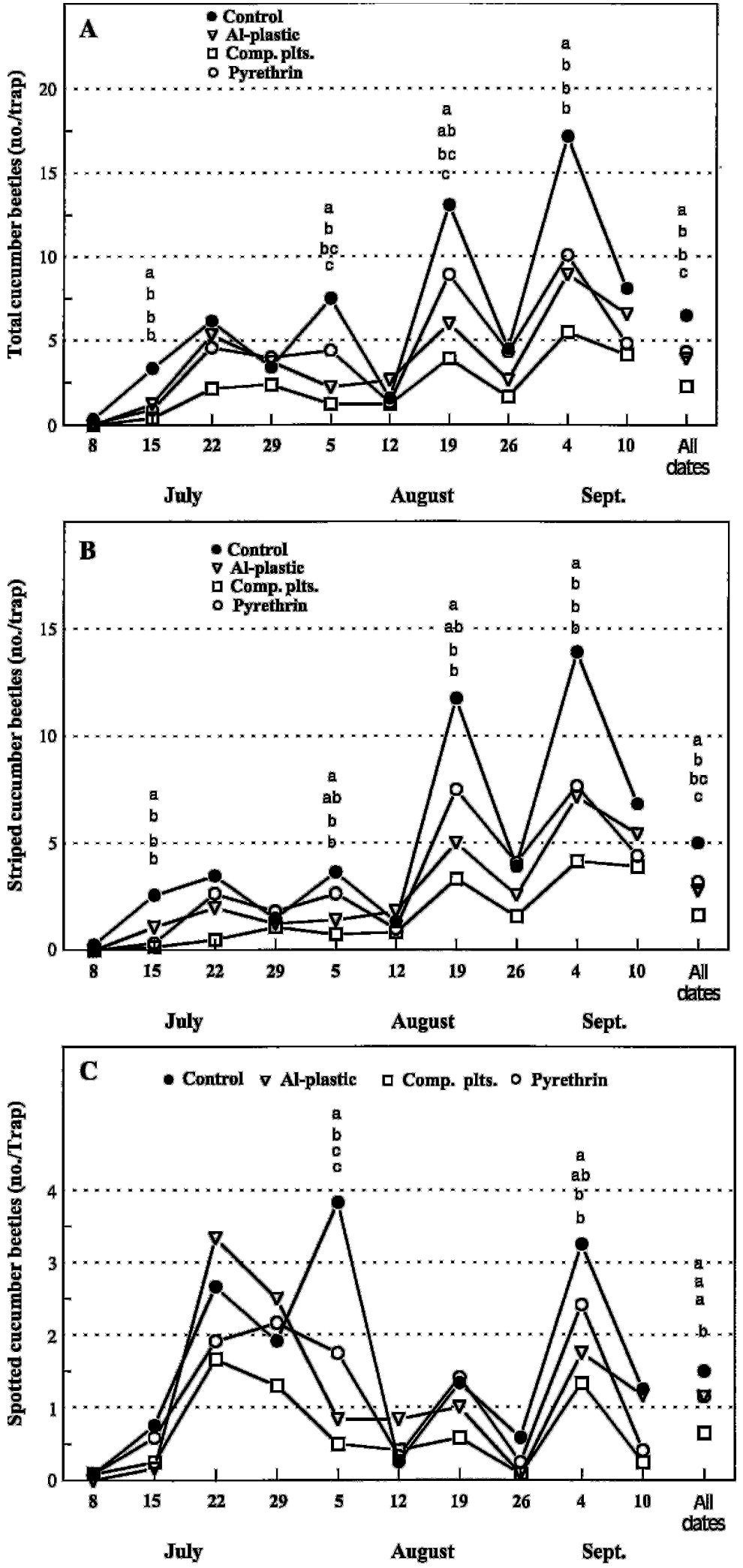

Fig. 2. Effects of pyrethrin, aluminum-coated plastic mulch (Al-plastic), and companion plants (Comp. plots) on numbers of trapped (A) total cucumber beetles, (B) striped cucumber beetles, and (C) spotted cucumber beetles in 2003 in muskmelon grown at Frankfort, KY. On each date, values followed by different letters were significantly different $(P \leq 0.05)$. 
(Table 2). Muskmelon numbers from the companion plant treatment were also significantly greater (39\%) than in the control. No significant differences were detected between yields from the Al-plastic and companion plant treatments or between yields from the pyrethrin and control treatments.

VINE COVER. On both sampling dates, the response of vine cover to main plot treatments was generally similar to that of muskmelon yields (Table 2). Vine cover obtained using Al-plastic was highest and significantly greater than cover in the control or pyrethrin treatments. Vine cover in the companion plant treatment was intermediate between cover in Al-plastic and control treatments and was not significantly different from cover in other treatments. Lower vine cover on the later sampling date appeared due to increased beetle damage and vine maturation. Other than cucumber beetles, no significant numbers of other insect pests or diseases were observed on the crop. The University of Kentucky Plant Diagnostic Laboratory detected no diseases and only beetle feeding on damaged plants, suggesting that treatment effects on vine cover and melon yields were due to cucumber beetles.

Cucumber beetles. The numbers of trapped total cucumber beetles were consistently greater in the control than in $\mathrm{Al}$-plastic and the companion plant treatments. These differences were significant on four dates and for all dates combined (Fig. 1A). In the pyrethrin treatment, the numbers of trapped total cucumber beetles were significantly less than in the control on three dates and for all dates combined; however, they were also significantly greater than those in the companion plant treatment on two dates and for combined dates. Differences in the numbers of trapped total beetles between $\mathrm{Al}$-plastic and the companion plant treatments were not significant on any date; however, the numbers tended to greater in the Al-plastic treatment, and this difference was significant for all dates combined. There were no significant differences between the numbers of total cucumber beetles trapped in pyrethrin and Al-plastic treatments.

Treatment effects on the numbers of trapped striped cucumber beetles agreed with those for total cucumber beetles; however, there were fewer significant differences among treatments (Fig. 1B). The numbers of trapped striped beetles in the pyrethrin treatment were significantly less than the numbers in the control on only two dates, and the numbers of striped beetles trapped in $\mathrm{Al}$-plastic and companion plant treatments were not significantly different for combined dates.

Fewer numbers of spotted cucumber beetles were trapped than striped beetles, and significant treatment differences results only occurred on two dates for spotted beetles (Fig. IC). However, results generally agreed with those obtained for striped and total cucumber beetles.

The use of Al-plastic and companion plants significantly increased yields and decreased the numbers of trapped cucumber beetles. However, the means by which these treatments affected yields did not appear identical. Muskmelon yields were significantly greater $(40 \%)$ using $\mathrm{Al}$-plastic than in the pyrethrin treatment, yet the numbers of total cucumber beetles trapped in the pyrethrin treatment never significantly exceeded the numbers trapped in the $\mathrm{Al}$-plastic treatment (Table 2, Fig. 2A). Also, the numbers of total cucumber beetles trapped using companion plants were significantly lower than those in the Al-plastic treatment for all dates combined, but treatment yields were not significantly different and even tended to greater using Al-plastic.
These data suggested that Al-plastic may have reduced early season beetle egg deposition in the soil, thereby decreasing larval root damage and reducing the numbers of beetles emerging later in the season. This contention is also supported by the fact that $\mathrm{Al}$-plastic significantly reduced the numbers of trapped beetles over the entire growing season well after the vines covered the plastic. Yield increases obtained in the companion plant treatment were probably solely caused by companion plants reducing populations of adult cucumber beetles. In this treatment, less than five total beetles per trap were obtained until well into the harvest season when the value reached 5.3 on 4 Sept. (Fig. 1A).

\section{Rowcover subplot effects}

MUSKMELON YIELDS. The use of rowcovers for $24 \mathrm{~d}$ after planting significantly increased total melon weight $(47 \%)$ and melon numbers (49\%; Table 2). Rowcovers were included in this study to prevent damage or the loss of small muskmelon seedlings to cucumber beetle feeding damage shortly after planting. However, in the absence of rowcovers, no seedlings were lost and early beetle damage appeared minimal. Thus, the large yield increases obtained by using rowcovers were not caused by eliminating early feeding damage. This was similar in nature to observations made by Lopez (1998) in squash and by Santos et al. (1995) in muskmelon. In squash, rowcovers have proven

Table 3. Effects of treatments on yields and vine cover of muskmelon grown in 2004 at Frankfort, KY.

\begin{tabular}{|c|c|c|c|c|c|}
\hline \multirow[b]{2}{*}{ Treatments } & \multicolumn{2}{|c|}{ Muskmelon yields } & \multicolumn{2}{|c|}{ Vine cover $(\%)$} & \multirow{2}{*}{$\begin{array}{c}\text { Mean } \\
\text { melon } \\
\text { wt }(1 \mathrm{lb})^{\mathrm{x}}\end{array}$} \\
\hline & (tons $/$ acre $)^{\mathrm{z}}$ & $\begin{array}{c}(1000 \\
\text { melons } / \text { acre })^{\mathrm{y}}\end{array}$ & $\begin{array}{c}3 \\
\text { Aug. }\end{array}$ & $\begin{array}{c}14 \\
\text { Aug. }\end{array}$ & \\
\hline \multicolumn{6}{|l|}{ Main plot treatments } \\
\hline Control & $11.6 \mathrm{~d}^{\mathrm{w}}$ & $4.97 \mathrm{c}$ & $70 \mathrm{~d}$ & $58 \mathrm{~d}$ & $4.60 \mathrm{~d}$ \\
\hline $\mathrm{Al}$-plastic ${ }^{\mathrm{v}}$ & $19.9 \mathrm{~b}$ & $7.77 \mathrm{a}$ & $87 \mathrm{~b}$ & $77 \mathrm{a}$ & $5.02 \mathrm{~b}$ \\
\hline Comp. plant $\mathrm{t}^{\mathrm{u}}$ & $15.1 \mathrm{c}$ & $6.09 \mathrm{~b}$ & $79 \mathrm{c}$ & $71 \mathrm{c}$ & $4.88 \mathrm{c}$ \\
\hline $\mathrm{Al}$-plastic + Comp. plant & $22.8 \mathrm{a}$ & $8.60 \mathrm{a}$ & $90 a$ & $79 \mathrm{a}$ & $5.19 \mathrm{a}$ \\
\hline \multicolumn{6}{|l|}{ Subplot treatments } \\
\hline No rowcovers & $12.7 \mathrm{~b}$ & $5.78 \mathrm{~b}$ & $77 \mathrm{~b}$ & $66 \mathrm{~b}$ & $5.48 \mathrm{a}$ \\
\hline Rowcovers & $22.0 \mathrm{a}$ & $7.93 \mathrm{a}$ & $86 a$ & $77 \mathrm{a}$ & $4.36 \mathrm{~b}$ \\
\hline
\end{tabular}

${ }^{\mathrm{z}} 1$ ton $/$ acre $=2.2417 \mathrm{Mg} \cdot \mathrm{ha}^{-1}$

y 1000 melons $/$ acre $=2471.1$ melons $/$ ha

${ }^{x} 1 \mathrm{lb}=0.4536 \mathrm{~kg}$.

whithin each group of main or subplot treatments, values followed by different letters were significantly different $(P \leq 0.05)$.

vAluminum-coated plastic mulch treatment.

"Companion plant treatment. 
beneficial in controlling cucumber flea beetles (Epitrix cucumeris), squash bugs (Anasa tristis), and viral disease carried by the insect vector, whitefly (Bemisia tabaci; Adams et al., 1990; Cartwright et al., 1990; Lopez, 1998).

VINe COVER. The use of rowcovers increased vine cover on both assessment dates, and the increase $(33 \%)$ was significant on the second date, 27 Aug. (Table 2). Immediately after rowcover removal, plant growth appeared greater for previously covered vines due to increased leaf size (Lopez, 1998; Salisbury and Ross, 1978). At the time of rowcover removal, vine damage was minimal in both rover cover treatments. However, as the season progressed, vine damage appeared greater on plants not previously receiving covers, and beneficial rowcover effects on yields and vine cover appeared more related to lower pest damage than to increased vine growth. Field observations and plant analysis by The University of Kentucky Plant Diagnostic Laboratory indicated that plants not receiving rowcovers possessed no disease or insect damage other than that caused by beetles.

Cucumber beetles. After the rowcovers were removed, there were no significant differences in trapped beetle numbers between rowcover treatments on any dates or for combined dates.

The causes of beneficial rowcover effect were not clear. Early enhanced vine growth/leaf size obtained under rowcovers may have contributed to later increases in vine cover and yields; however, it seemed unlikely that these early season effects could increase yields by almost $50 \%$. Furthermore, reduced vine cover without rowcovers appeared more due to vine damage than growth as noted previously. Rowcovers may have prevented early season egg deposition by beetles, which may have reduced larval crop damage later in the season.

\section{4 experiment}

As in 2003, interaction between main and subplot treatment effects on all dependent variables was not significant, thus main plot treatments were analyzed for combined rowcover treatments and vice versa.
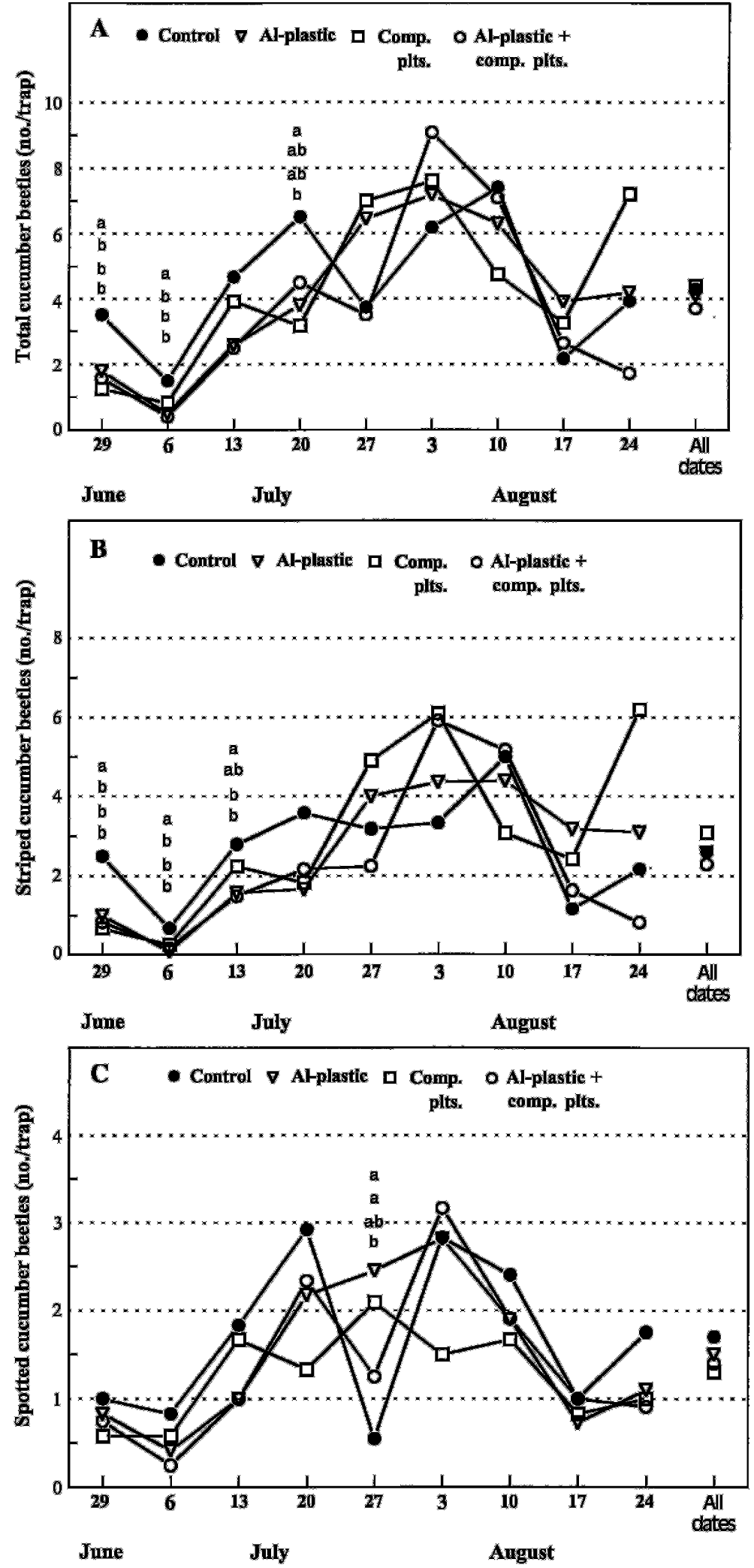

Fig. 3. Effects of aluminum-coated plastic mulch (Al-plastic) and companion plants (Comp. plots) on numbers of trapped (A) total cucumber beetles, (B) striped cucumber beetles, and (C) spotted cucumber beetles in 2004 in muskmelon grown at Frankfort, KY. On each date, values followed by different letters were significantly different $(P \leq \mathbf{0 . 0 5})$. 


\section{Main plot treatment effects}

MUSKMELON YIELDS. In 2004, total muskmelon weights in all four treatments were significantly different (Table 3 ). Weights were greatest in the Al-plastic + companion plant treatment and were lowest in the control treatment. Weights in the $\mathrm{Al}$-plastic treatment were greater than in the companion plant treatment. Compared with the control, melon weights were $30 \%, 72 \%$, and $96 \%$ higher in the companion plant, $\mathrm{Al}$ plastic, and Al-plastic + companion plant treatment plots, respectively. Treatment effects on melon numbers were similar to weights except that no significant difference was detected between numbers in the Al-plastic and companion plant treatments (Table 3). Compared with the control, melon numbers were $11 \%, 56 \%$, and $72 \%$ higher in the companion plant, Al-plastic, and Al-plastic + companion plant treatments, respectively. Thus, increases in muskmelon weights and numbers obtained using Al-plastic and companion plants appeared additive, indicating that these treatments probably affected yields by different means as suggested by 2003 results.

Average weights of individual melons were significantly different among all main plot treatments, and relative treatment effects were similar to those described for total weights (Table 3).

VINE COVER. On both assessment dates, responses of vine cover to all main plot treatments were significantly different and almost identical to muskmelon yield responses (Table 3 ). Vine cover was significantly less in the control than in other treatments. Treatment differences appeared related to cucumber beetles because treatment effects on vine damage were similar to those obtained in 2003, which were attributed to cucumber beetles. As in 2003 , vine cover was lower on the later assessment date.

Cucumber beetles. On the first four sampling dates of 2004, treatment effects on the numbers of trapped cucumber beetles were generally similar to those obtained in 2003 (Figs. 2 and 3). Early season numbers of trapped beetles in 2004 tended to be greatest in the control, and this difference was significant for total and striped beetles on three early sampling dates (Fig. 3, A and B). After 20 July, there were no trends in the treatment effects on the numbers of trapped beetles, although an unexplained significant treatment effect occurred on 27 July for spotted beetles (Fig. 3). For combined dates, the average numbers of trapped beetles did not differ significantly among treatments. The lack of treatment effects on mid- to late-season numbers of trapped beetles was unexpected and differed from results in 2003, when treatment differences in trapped beetles occurred over the entire season and supported the contention that treatment effects on muskmelon yields and vine cover were related to cucumber beetles. Frequent and abundant rainfall in 2004 may have reduced trap efficacy or the propensity of beetles to fly and be trapped. According to the University of Kentucky Agricultural Weather Center 25 miles from the experimental site, combined July and Aug. 2004 rainfall (13 inches) was $43 \%$ above normal, whereas rainfall ( 9 inches) was only $3 \%$ above normal in 2003 during the same period.

\section{Rowcover subplot effects}

MUSKMELON YIELDS. As in 2003 , the use of rowcovers significantly increased the total weights and numbers of muskmelons, which were $73 \%$ and $37 \%$ for melon weight and numbers, respectively (Table 3 ). The average weights of individual melons were also significantly increased by $26 \%$ when rowcovers were used.

VINE COVER. Muskmelon vine cover was significantly greater with rowcovers than without rowcovers on both assessment dates in 2004 (Table 3 ), and the difference appeared more related to vine damage than vine growth as in 2003 .

Cucumber beetles. No significant differences in beetle catches on any date were detected after rowcover removal.

\section{3 and 2004 treatment combinations}

Previously, 2002 and 2003 main plot treatment effects were determined for combined subplot treatments and vice versa, resulting in separate discussion of main and subplot treatment effects (Tables 2 and $3)$. Table 4 describes 2002 and 2003 mean yields for individual main plot and subplot treatment combinations, including a completely untreated control (i.e., main plot control without rowcovers). Mean separation statistical analysis was not included due to lack of randomization among these

Table 4. Effects of main and subplot treatment combinations on muskmelon yields in 2003 and 2004 at Frankfort, KY.

\begin{tabular}{|c|c|c|c|c|c|}
\hline \multicolumn{2}{|c|}{ Treatment combination } & \multicolumn{2}{|c|}{2003 Yields } & \multicolumn{2}{|c|}{2004 Yields } \\
\hline Main plot treatments & Rowcovers & ${\text { (tons } / \text { acre })^{\mathrm{z}}}$ & $(1000 \text { melons } / \text { acre })^{y}$ & (tons/acre) & (1000 melons/acre) \\
\hline $\mathrm{Al}$-plastic ${ }^{\mathrm{x}}+$ comp. plant $^{\mathrm{v}}$ & Yes & 一 & - & 28.4 & 9.8 \\
\hline Comp. plant & Yes & 25.5 & 9.1 & 19.3 & 7.1 \\
\hline $\mathrm{Al}$-plastic + comp. plant & No & - & - & 16.9 & 7.3 \\
\hline Al-plastic & No & 25.5 & 8.7 & 14.7 & 6.6 \\
\hline Control & Yes & 19.8 & 7.7 & 14.9 & 5.8 \\
\hline Pyrethrin & No & 12.0 & 4.3 & - & - \\
\hline Control & No & 12.4 & 4.7 & 7.1 & 3.4 \\
\hline
\end{tabular}

${ }^{\mathrm{z}} \mathrm{l}$ ton $/$ acre $=2.2417 \mathrm{Mg} \cdot \mathrm{ha}^{-1}$

${ }^{y} 1000$ melons $/$ acre $=2471.1$ melons $/$ ha

xAluminum-coated plastic mulch.

${ }^{v}$ Companion plants. 
treatment combinations in the split plot design; however, the use of all individual main plot or subplot treatments except pyrethrin significantly increased yields compared with appropriate controls in the prior combined statistical analyses (Tables 2 and 3 ). Also, the lack of interaction between yield effects of main and subplot treatments predicted that yield effects of these treatments should be largely independent and thus somewhat synergistic in Table 4.

In Table 4, the beneficial main and subplot treatments that increased yields in previous combined analyses (Tables 2 and 3 ) tended to produce large yield increases compared with the main plot control treatment without rowcovers. Yields from these beneficial main and subplot treatments tended to increase when these treatments were combined, implying that such combinations produced synergistic yield effects and suggesting that individual treatments acted somewhat independently. Such apparent synergism supported the contention that some treatments (i.e., companion plants) may have mainly affected adult beetle populations, whereas other treatments (i.e., rowcovers and, to a lesser extent, Al-plastic) may have affected populations of beetle larvae in the soil.

It was concluded that use of companion plants and Al-plastic increased muskmelon yields and vine cover while reducing populations of cucumber beetles. The use of rowcovers also increased muskmelon yields and vine cover.

\section{Literature cited}

Adams, R.G., R.A. Ashley, and M.J. Brennan. 1990. Row covers for excluding insect pests from broccoli and summer squash plantings. J. Econ. Entomol. 83:948-954.

Andino, J.R. and C.E. Motsenbocker. 2004. Colored plastic mulches influence cucumber beetle populations, vine growth, and yield of watermelon. HortScience 39:1246-1249.

Bach, C. 1980a. Effects of plant diversity and time of colonization on an herbivoreplant interaction. Oecologia 44:319-326.

Bach, C. 1980b. Effects of plant density and diversity on the population dynamics of a specialist herbivore, the striped cucumber beetle Acalymma vittata. Ecology 61:1515-1530.

Bach, C. 1988. Effects of host plant patch size on herbivore density: Underlying mechanisms. Ecology 69:1103-1117.

Bowman, G., C. Shirley, and C. Cramer. 1998. Managing cover crops profitably. Sustainable Agriculture Network, Beltsville, $\mathrm{MD}$.

Brust, G.E. and R.E. Foster. 1999. New economic threshold for striped cucumber beetle in cantaloupe in the Midwest. Hort. Entomol. 92:936-940.

Caldwell, J.S. and P. Clarke. 1998. Aluminum-coated plastic for repulsion of cucumber beetles. Virginia Cooperative Extension. Commercial Hort. Nwsl. Jan.-Feb. 1998. 3 Apr. 2008. <http:// www.ext.vt.edu/news/periodicals/ commhort/1998-02/1998-02-01.html>.

Caldwell, J.S. and P. Clarke. 1999. Repulsion of cucumber beetles in cucumber and squash using aluminum-coated plastic mulch. HortTechnology 9:247256.

Cartwright, B., J.C. Palumbo, and W.S. Fargo. 1990. Influence of crop mulches and row covers on the population dynamics of the squash bug (Heteroptera Coreidae) on summer squash. J. Econ. Entomol. 83:1988-1993.

Hoffman, M. 1998. Integrated pest management for cucumber beetles, p. 38-39. In: K.A. Stoner (ed.). Alternatives to insecticides for managing vegetable insects. National Resource, Agriculture, and Engineering Service, New Haven, CT.

Jolly, D. 1998. Organics on the brink. Organic Res. Foundation Info. Bull. 5(1):1-16.

Lopez, M.V. 1998. Growth, yield and leaf NPK concentrations in crop-covered squash. J. Sustainable Agr. 12:25-34.

Platt, J.O., J.S. Caldwell, and L.T. Kok. 1999. Effect of buckwheat as a flowering border on populations of cucumber beetles and their natural enemies in cucumber and squash. Crop Prot. 18:305-313.

Rodale Press. 1978. Encyclopedia of organic gardening. Rodale Press, Emmaus, PA.

Rowell, B., J. Strang, T. Jones, R. Bessin, and W. Nesmith. 2002. Vegetable production guide. Univ. Kentucky Coop., Ext. Serv. ID 36.

Salisbury, F.B. and C.W. Ross. 1978. Plant physiology, 2nd ed. Wadsworth Publishing, Belmont, CA.

Santos, M.O., O.P. Zamora, and O.L. Arriaga. 1995. Floating row cover and transparent mulch to reduce insect populations, virus diseases, and increase yield in cantaloupe. Fla. Entomol. 78:493502.

Smith, M. and E. Henderson. 1998. The real dirt: Farmers tell about organic and low-input practices in the Northeast. Northeast Organic Farming Assn. and Cooperative Extension, Burlington, VT.

U.S. Department of Agriculture. 1997a. United States standards for grades of watermelons. U.S. Dept. Agr., Washington, DC.

U.S. Department of Agriculture. 1997b. United States standards for grades of cantaloupes. U.S. Dept. Agr., Washington, DC.

Ware, G.W. 1994. The pesticide book. Thomas Publications, Fresno, CA. 